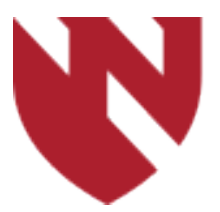

September 2020

\title{
Advance Care Planning: A Quality Improvement Project to Increase Patient Access and Provider Reimbursement
}

\author{
Michael Dobson \\ University of Nebraska Medical Center \\ Richard Fruehling \\ University of Nebraska Medical Center
}

Tell us how you used this information in this short survey.

Follow this and additional works at: https://digitalcommons.unmc.edu/gmerj

Part of the Higher Education Commons, and the Medicine and Health Sciences Commons

\section{Recommended Citation}

Dobson, M., , Fruehling, R. Advance Care Planning: A Quality Improvement Project to Increase Patient Access and Provider Reimbursement. Graduate Medical Education Research Journal. 2020 Sep 29; 2(1). https://digitalcommons.unmc.edu/gmerj/vol2/iss1/47

This Conference Proceeding is brought to you for free and open access by DigitalCommons@UNMC. It has been accepted for inclusion in Graduate Medical Education Research Journal by an authorized editor of DigitalCommons@UNMC.For more information, please contact digitalcommons@unmc.edu. 
Advance Care Planning: A Quality Improvement Project to Increase Patient Access and Provider Reimbursement

\section{Creative Commons License}

\section{(c) (1) $\Theta(9$}

This work is licensed under a Creative Commons Attribution-Noncommercial-No Derivative Works 4.0 License. 


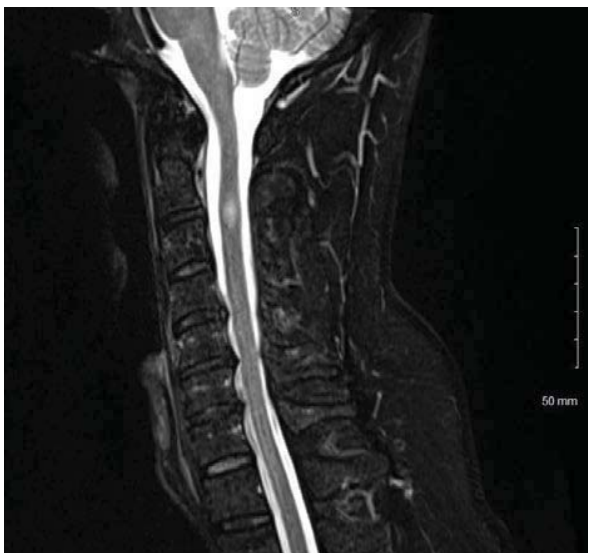

onset of symptoms, we cannot infer a causal relationship between the two. While CESIs are a safe intervention, including in patients with multiple sclerosis, physicians must always be vigilant for red flag symptoms including fever, chills, worsening pain, loss of bladder or bowel function, weakness, and new onset of sensory deficits. Timely workup decreases the time between symptom onset and diagnosis which may reduce the risk of permanent neurologic deficits.

https://doi.org/10.32873/unmc.dc.gmerj.2.1.044

Figure 1. MRI of cervical spine 48 hours after cervical epidural steroid injection (C6-7 level) demonstrating a new, enhancing spinal cord lesion at $\mathrm{C} 2$ and $\mathrm{C} 3$ consistent with active demyelination.

\section{Advance Care Planning: A Quality Improvement Project to Increase Patient Access and Provider Reimbursement \\ Michael Dobson', Richard Fruehling ${ }^{1}$ \\ ${ }^{1}$ University of Nebraska Medical Center, Department of Family Medicine}

Mentor: Richard Fruehling

Program: Family Medicine - Rural Medicine

Type: Original Research

Background: Advanced care planning (ACP) is an important intervention that improves end of life care. In 2016, CMS introduced new billing codes to reward providers already performing $\mathrm{ACP}$, and to incentivize those who were not. In 2016 - the year the codes were introduced - national data indicated only $1.9 \%$ of Medicare beneficiaries over 65 had an ACP claim during any visit. In 2017 this increased to $2.2 \%$. Among a group practice of fourteen providers in Grand Island, Nebraska, no claims had ever been made before October of 2019 .

Methods: A short, one hour information session provided guidance on the new ACP codes as well as evidence-based strategies for having these often difficult conversations. Claims made over the next two months were measured, along with corresponding data about setting, and patient characteristics.

Results: In just two months, over one hundred claims were made in this group practice, mostly during Medicare wellness visits but also across many settings including nursing homes and inpatient admissions. Providers reported that after the information session they were better equipped and more willing to provide ACP and properly bill for the service.

Conclusion: ACP was already performed by these providers before the information session but after the session they were more willing to engage their patients in ACP and captured a significant amount of revenue. We believe this information session could be easily replicated to expand ACP and improve the dismal national reimbursement.

https://doi.org/10.32873/unmc.dc.gmerj.2.1.046

\section{Association of Agricultural, Occupational and Military Inhalants With Autoantibodies and Disease Severity in U.S. Veterans with Rheumatoid Arthritis}

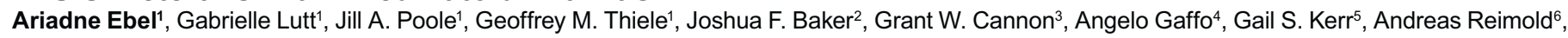
Pascale Schwab ${ }^{7}$, Namrata Singh ${ }^{8}$, Steuart Richards ${ }^{9}$, Dana P. Ascherman ${ }^{9}$, Ted R. Mikuls ${ }^{1}$, Bryant R. England ${ }^{1}$

${ }^{1}$ University of Nebraska Medical Center, Department of Internal Medicine, Division of Rheumatology

${ }^{2}$ Philadelphia VA \& University of Pennsylvania, Philadelphia, PA

${ }^{3}$ Salt Lake City VA \& University of Utah, Salt Lake City, UT

${ }^{4}$ Birmingham VA \& University of Alabama at Birmingham, Birmingham, $\mathrm{AL}$

${ }^{5}$ Washington DC VA, Georgetown, \& Howard University, Washington DC

${ }^{6}$ Dallas VA \& University of Texas Southwestern, Dallas, TX

${ }^{7}$ Portland VA \& Oregon Health Science University, Portland, OR

${ }^{8}$ Iowa City VA \& University of lowa, lowa City, IA

${ }^{9}$ Pittsburg VA \& University of Pittsburgh

Mentor: Bryant R. England

Program: Internal Medicine, Division of Rheumatology

Type: Original Research
Background: Cigarette smoke is a known inhalant exposure that contributes substantially to the risk and severity of rheumatoid arthritis (RA). Less is known about the link between other inhalant exposures and RA. The aim of this study was to determine the association between occupational, agricultural, and military inhalant exposures with RA-related factors.

Methods: Participants at nine sites in the Veterans Affairs Rheumatoid Arthritis 